\title{
Hydrogen peroxide distribution, production, and decay in boreal lakes
}

\author{
Petri J. Häkkinen, Alexandre M. Anesio, and Wilhelm Granéli
}

\begin{abstract}
The distribution, production, and decay of hydrogen peroxide $\left(\mathrm{H}_{2} \mathrm{O}_{2}\right)$ were studied in 10 boreal lakes of differing physical-chemical characteristics. Diurnal and vertical fluctuations in $\mathrm{H}_{2} \mathrm{O}_{2}$ concentration were followed in the lakes by sampling at six depths three times per day. In addition, incubations of water filtered through $0.2-\mu \mathrm{m}$ mesh were made under artificial irradiation to study the abiotic production and decay of $\mathrm{H}_{2} \mathrm{O}_{2} \cdot \mathrm{H}_{2} \mathrm{O}_{2}$ concentrations after $8 \mathrm{~h}$ of artificial irradiation were significantly correlated with neither absorption coefficients at $320 \mathrm{~nm}$ nor with dissolved organic carbon (DOC) concentrations. However, $\mathrm{H}_{2} \mathrm{O}_{2}$ concentration increased rapidly with DOC concentration among lakes with DOC concentrations below $10 \mathrm{mg} \cdot \mathrm{L}^{-1}$. The $\mathrm{H}_{2} \mathrm{O}_{2}$ concentration after exposure to ultraviolet radiation was positively related to the half-life of $\mathrm{H}_{2} \mathrm{O}_{2}$, which in turn was negatively correlated with iron and manganese concentrations $\left(r^{2}=0.68\right.$ and 0.70 , respectively). In situ $\mathrm{H}_{2} \mathrm{O}_{2}$ concentrations at the surface of the water column ranged between 30 and $1041 \mathrm{nmol} \cdot \mathrm{L}^{-1}$ and were largely determined by the decay rates of $\mathrm{H}_{2} \mathrm{O}_{2}$ and the mixing depth of the water column.
\end{abstract}

Résumé : Nous avons étudié la répartition, la production et la décomposition du peroxyde d'hydrogène $\left(\mathrm{H}_{2} \mathrm{O}_{2}\right)$ dans 10 lacs de la région boréale qui possèdent des caractéristiques physicochimiques différentes. Nous avons fait des prélèvements à six profondeurs, trois fois par jour, dans les lacs afin de suivre les fluctuations journalières et verticales des concentrations d' $\mathrm{H}_{2} \mathrm{O}_{2}$. De plus, nous avons incubé de l'eau filtrée sur un filtre de $0,2 \mu \mathrm{m}$ sous irradiation artificielle afin d'observer la production et la décomposition abiotiques d' $\mathrm{H}_{2} \mathrm{O}_{2}$. Après $8 \mathrm{~h}$ d'incubation sous irradiation artificielle, il n'y a pas de corrélation significative entre les concentrations d' $\mathrm{H}_{2} \mathrm{O}_{2}$ et les coefficients d'absorption à $320 \mathrm{~nm}$, ni entre ces concentrations et le carbone organique dissous (DOC). Cependant, les concentrations d' $\mathrm{H}_{2} \mathrm{O}_{2}$ augmentent rapidement en fonction de DOC dans les lacs qui ont des concentrations de DOC inférieures à $10 \mathrm{mg} \cdot \mathrm{L}^{-1}$. Après une exposition à le rayonnement ultraviolet, la concentration d' $\mathrm{H}_{2} \mathrm{O}_{2}$ est en corrélation positive avec la demi-vie d' $\mathrm{H}_{2} \mathrm{O}_{2}$, qui, à son tour, est en corrélation négative avec le fer et manganèse ( $r^{2}=0,68$ et 0,70 , respectivement). Les concentrations d' $\mathrm{H}_{2} \mathrm{O}_{2}$ in situ en surface de la colonne d'eau varient de 30 à $1041 \mathrm{nmol} \cdot \mathrm{L}^{-1}$ et s'expliquent en grande partie par les taux de décomposition d' $\mathrm{H}_{2} \mathrm{O}_{2}$ et la profondeur du brassage dans la colonne d'eau.

[Traduit par la Rédaction]

\section{Introduction}

The interaction between ultraviolet (UV) radiation and dissolved organic carbon (DOC) can result in the formation of chemically reactive and biologically toxic compounds, including hydroxyl- and alkyl-peroxyl radicals (Mill et al. 1980), superoxides, and hydrogen peroxide $\left(\mathrm{H}_{2} \mathrm{O}_{2}\right)$ (Cooper et al. 1988). $\mathrm{H}_{2} \mathrm{O}_{2}$ is long-lived compared with other oxidants and radicals and is measurable by simple methods, making it a useful marker of DOC photolysis and of the photochemical production of oxidizing agents (Cooper et al. $1989 b$ ). Diel patterns of $\mathrm{H}_{2} \mathrm{O}_{2}$ concentration in surface waters have been observed in several studies, with higher concentrations during the day and lower during the night (Cooper et al. 1989a; Herrmann 1996; Wilson et al. 2000a).
This pattern suggests that photochemical formation is the major production mechanism of $\mathrm{H}_{2} \mathrm{O}_{2}$ in fresh waters and seawater (Cooper and Zepp 1990). In addition, biological (Wilson et al. 2000b) and trace metal mediated production in darkness (Moffett and Zika 1987), as well as wet and dry deposition (Miller and Kester 1994), can contribute to the $\mathrm{H}_{2} \mathrm{O}_{2}$ concentration in natural waters.

Typical $\mathrm{H}_{2} \mathrm{O}_{2}$ concentrations between 10 and $400 \mathrm{nmol} \cdot \mathrm{L}^{-1}$ at the surface have been reported in a number of different types of aquatic ecosystems (Cooper et al. 1989a; Kieber and Helz 1995; Herrmann 1996). $\mathrm{H}_{2} \mathrm{O}_{2}$ concentrations up to $800 \mathrm{nmol} \cdot \mathrm{L}^{-1}$ in lakes have also been observed (Cooper and Lean 1989), a level that is inhibitory to bacteria (Xenopoulos and Bird 1997). In most cases, $\mathrm{H}_{2} \mathrm{O}_{2}$ concentrations are higher in fresh waters than in the sea, while estuarine re-

Received 28 April 2003. Accepted 6 April 2004. Published on the NRC Research Press Web site at http://cjfas.nrc.ca on 3 November 2003.

J17495

P.J. Häkkinen, A.M. Anesio, ${ }^{\mathbf{1 , 2}}$ and W. Granéli. Department of Ecology/Limnology, Lund University, 22362 Lund, Sweden.

${ }^{1}$ Corresponding author (e-mail: lab@aber.ac.uk).

${ }^{2}$ Present address: Institute of Biological Sciences, England Llwyd Building, University of Wales, Aberystwyth, SY23 3DA, UK. 
Table 1. Description of the lakes in this study.

\begin{tabular}{|c|c|c|c|c|c|c|c|}
\hline Lake & Location $^{a}$ & $\begin{array}{l}\text { DOC concn. } \\
\left(\mathrm{mg} \cdot \mathrm{L}^{-1}\right)^{b}\end{array}$ & $\mathrm{pH}$ & $\begin{array}{l}\text { Iron conen. } \\
\left(\mu \mathrm{g} \cdot \mathrm{L}^{-1}\right)^{c}\end{array}$ & $\begin{array}{l}\text { Manganese } \\
\text { concn. }\left(\mu \mathrm{g} \cdot \mathrm{L}^{-1}\right)^{c}\end{array}$ & $\begin{array}{l}\mathrm{UV}-\mathrm{A} \\
\left(\mathrm{kJ} \cdot \mathrm{m}^{-2}\right)^{d}\end{array}$ & $\begin{array}{l}\text { Absorptivity at } \\
320 \mathrm{~nm} \cdot \mathrm{m}^{-1}\end{array}$ \\
\hline Klintsjön & $57^{\circ} 08^{\prime}, 14^{\circ} 42^{\prime}$ & 3.1 & 5.3 & 44 & 59.7 & 524 & 6.0 \\
\hline Skärlen & $57^{\circ} 11^{\prime}, 14^{\circ} 52^{\prime}$ & 3.6 & 6.0 & 2.5 & 2.9 & 492 & 5.6 \\
\hline Hindsen & $57^{\circ} 13^{\prime}, 14^{\circ} 09^{\prime}$ & 5.0 & 7.2 & 8.2 & 1.3 & 575 & 12.2 \\
\hline Övingen & $57^{\circ} 14^{\prime}, 14^{\circ} 43^{\prime}$ & 6.8 & 6.9 & 13 & 1.2 & 301 & 15.7 \\
\hline Homeshultasjön & $57^{\circ} 13^{\prime}, 14^{\circ} 50^{\prime}$ & 9.5 & 7.2 & 41 & 1.1 & 557 & 27.7 \\
\hline Älgarydssjön & $57^{\circ} 11^{\prime}, 14^{\circ} 17^{\prime}$ & 12.4 & 5.3 & 1110 & 6.4 & 553 & 61.2 \\
\hline Skärshultsjön & $57^{\circ} 09^{\prime}, 14^{\circ} 31^{\prime}$ & 17.2 & 6.1 & 983 & 81.4 & 408 & 87.9 \\
\hline Grunnen & $57^{\circ} 10^{\prime}, 14^{\circ} 26^{\prime}$ & 19.4 & 7.2 & 1080 & 15.3 & 487 & 107.7 \\
\hline
\end{tabular}

\footnotetext{
${ }^{a}$ Geographic coordinates are given as latitude (N) and longitude (E).

${ }^{b}$ Dissolved organic carbon.

${ }^{c}$ Total concentration.

${ }^{d}$ Integrated amount of ultraviolet-A radiation at the surface during the incubations in each lake, between 0900 and 1700 .
}

gions exhibit intermediate values (Kieber and Helz 1995). A positive relationship between DOC and $\mathrm{H}_{2} \mathrm{O}_{2}$-formation rates has been detected in previous studies (Cooper et al. 1988; Scully et al. 1996), which may partially explain the difference in $\mathrm{H}_{2} \mathrm{O}_{2}$ concentrations between freshwater and marine systems.

The decay of $\mathrm{H}_{2} \mathrm{O}_{2}$ is influenced by both biotic and abiotic factors and varies widely among different aquatic ecosystems. The decay of $\mathrm{H}_{2} \mathrm{O}_{2}$ may be affected by bacteria (Cooper and Zepp 1990) and other microorganisms (Cooper and Lean 1989), and by redox-sensitive metals such as iron (Moffett and Zafiriou 1993) and manganese (Sunda and Huntsman 1994). The possibility has often been raised that biological decay is the main mechanism of $\mathrm{H}_{2} \mathrm{O}_{2}$ decay, at least in coastal and marine surface waters (Moffett and Zafiriou 1990). Only a few studies in which $\mathrm{H}_{2} \mathrm{O}_{2}$ decay was considered have been conducted in metal- or DOC-rich waters (Tranvik and Kokalj 1998; Wilson et al. 2000b). Humic lakes are usually distinguished by the presence of high amounts of metals, which can be reduced by $\mathrm{H}_{2} \mathrm{O}_{2}$. Sunda and Huntsman (1994) found an approximately fivefold decrease in the rates of manganese dissolution after addition of $\mathrm{H}_{2} \mathrm{O}_{2}$ catalase during light exposure of simulated estuarine water. The results found by Sunda and Huntsman (1994) suggest that photodissolution of manganese oxides results mainly from manganese reduction by $\mathrm{H}_{2} \mathrm{O}_{2}$. Evidence from the literature also shows that $\mathrm{H}_{2} \mathrm{O}_{2}$ is involved in both reduction (King et al. 1993) and oxidation of iron (Moffett and Zika 1987).

The aim of this study was to determine the distribution, production, and decay of $\mathrm{H}_{2} \mathrm{O}_{2}$ in boreal lakes of differing physical-chemical characteristics. In situ measurements were undertaken to study the diurnal and depth distribution of $\mathrm{H}_{2} \mathrm{O}_{2}$. There are only few studies linking the factors that influence production and decay of $\mathrm{H}_{2} \mathrm{O}_{2}$ under laboratory conditions and the distribution of $\mathrm{H}_{2} \mathrm{O}_{2}$ in natural conditions. The main objective of this study was to emphasize the role of metals in the distribution of $\mathrm{H}_{2} \mathrm{O}_{2}$ in humic lakes, as most of the previous studies were conducted in seawater and clear-water lakes. Differences in DOC and metal concentrations among the lakes were hypothesized to influence pat- terns of $\mathrm{H}_{2} \mathrm{O}_{2}$ production and decay, thus providing a better explanation of $\mathrm{H}_{2} \mathrm{O}_{2}$ dynamics in fresh waters.

\section{Material and methods}

\section{Sampling locations}

Between 19 June and 7 July 2001, in situ $\mathrm{H}_{2} \mathrm{O}_{2}$ concentrations were measured in 10 oligotrophic lakes situated within the boreal region of the South Swedish Highlands. Chlorophyll $a$ and phosphorus concentrations in these lakes range between 3-12 and 1-14 $\mu \mathrm{g} \cdot \mathrm{L}^{-1}$, respectively (data not shown). The locations of lakes and their physical-chemical characteristics are presented in Table 1.

\section{Diurnal and vertical fluctuations in $\mathrm{H}_{2} \mathrm{O}_{2}$ concentration}

Diurnal and vertical fluctuations in $\mathrm{H}_{2} \mathrm{O}_{2}$ concentration were followed in one lake per day by sampling at six depths (i.e., surface and $0.5,1.0,1.5,2.0$, and $3.0 \mathrm{~m}$ ) in the euphotic zone of the water column three times per day $(0930,1230$, and 1530). The temperature at each sampling depth was also measured. Approximately 40-mL samples were collected from each depth in acid- $(10 \% \mathrm{HCl})$ and Milli-Q-rinsed glass bottles. Thereafter, triplicate 3-mL samples were added to $6-\mathrm{mL}$ vials containing $90 \mu \mathrm{L}$ of $\mathrm{N}$-acetyl-3,7-dihydroxyphenoxanine (APOXA) working solution (see below). The vials were placed in a rack on ice clamps covering the bottom of a cooling box. All samples were analyzed the same evening, and maximum storage time before analysis was approximately $10 \mathrm{~h}$.

\section{Measurements of $\mathrm{H}_{2} \mathrm{O}_{2}$ production under in situ conditions}

Incubations at the water surface were performed in each lake to measure $\mathrm{H}_{2} \mathrm{O}_{2}$ production under sterile conditions. A water sample was taken from the epilimnion of each lake, using a $2 \mathrm{~m}$ long Plexiglas ${ }^{\circledR}$ tube. Approximately $20 \mathrm{~L}$ of water each was emptied into an acid- and a Milli-Q-rinsed polycarbonate bottle. Sampling in a lake was done the day before the incubation in that lake. The same day as the sampling was done, the contents of the 20-L polycarbonate bottle were filtered through a Milli-Q-rinsed GF/A filter 
(147 mm, Gelman Sciences, Montréal, Quebec) and subsequently through a $0.2 \mu \mathrm{m}$ mesh membrane filter $(147 \mathrm{~mm}$, Gelman Sciences). The filtered water was put into a $10-\mathrm{L}$ glass bottle, which was then stored in a refrigerator until the in situ incubation the following day. Water from the 10-L glass bottle was distributed to quadruplicate quartz tubes (inner diameter $40 \mathrm{~mm}$, length $200 \mathrm{~mm}$, and volume $190 \mathrm{~mL}$ ). The tubes were suspended horizontally at the surface of the lake, with half of the tube above the water and half under the water. Quadruplicate tubes wrapped in aluminum foil were used as dark controls. The tubes were fixed horizontally on a steel-wire platform suspended from a wooden frame. All glassware used was previously acid- $(10 \% \mathrm{HCl})$ and Milli-Q-rinsed.

The daily variation in solar radiation was estimated by measuring the integrated amounts of UV-A radiation (315$400 \mathrm{~nm}$ ) between 0900 and 1600, using an IL 1400A radiometer (International Light Inc., Newburyport, Massachusetts, USA). In addition, downwelling radiation was measured in all lakes at $380 \mathrm{~nm}$ using a PUV-500 radiometer. The depth of $1 \%$ surface irradiance for radiation at $380 \mathrm{~nm}$ $\left(z 1 \%_{380 \mathrm{~nm}}\right)$ was calculated according to Kirk (1994). We chose $380 \mathrm{~nm}$ for calculating $1 \%$ surface irradiance because substantial $\mathrm{H}_{2} \mathrm{O}_{2}$ formation can still occur at this wavelength (Scully et al. 1996). Temperature profiles were also recorded with the PUV-500 radiometer during the sampling of water for $\mathrm{H}_{2} \mathrm{O}_{2}$ measurements (i.e., at 0930, 1230, and 1530). The depth of the epilimnion was determined on the basis of changes in temperature relative to depth (i.e., changes in temperature $\geq 1.5^{\circ} \mathrm{C} \cdot \mathrm{m}^{-1}$ were regarded as the boundary for a thermocline).

\section{Measurements of $\mathrm{H}_{2} \mathrm{O}_{2}$ production and decay in laboratory conditions}

An additional 10-L integrated sample (from 0-2 $\mathrm{m}$ depth) was taken during the field studies and stored at $4{ }^{\circ} \mathrm{C}$ in the dark for further laboratory measurements of $\mathrm{H}_{2} \mathrm{O}_{2}$ production and decay under light- and temperature-controlled conditions. Incubations under laboratory conditions were completed approximately 2 months after the in situ sampling and incubations. Approximately $200 \mathrm{~mL}$ of lake water from the $10-\mathrm{L}$ polycarbonate bottles was filtered through $0.2-\mu \mathrm{m}-\mathrm{mesh}$ filters. Thereafter, triplicate $25-\mathrm{mL}$ samples were distributed into quartz tubes ( $40 \mathrm{~mL}$ volume). The tubes were irradiated for $8 \mathrm{~h}$ under an artificial UV radiation source consisting of eight fluorescent tubes (UVA-340, Q-Panel Company, Cleveland, Ohio, USA) emitting UV-A $\left(15.0 \mathrm{~W} \cdot \mathrm{m}^{-2}\right)$, UV-B $\left(0.37 \mathrm{~W} \cdot \mathrm{m}^{-2}\right)$, and photosynthetically active radiation (PAR; $\left.5.17 \mathrm{~W} \cdot \mathrm{m}^{-2}\right)$. Average irradiation values for the incubations in the field at noon on a cloudless day were 24.1, 0.33, and 365 $\mathrm{W} \cdot \mathrm{m}^{-2}$ for UV-A, UV-B, and PAR, respectively, at the surface of the water column. The integrated amount of UV-A radiation received externally by the tubes during the artificial irradiation was $432 \mathrm{~kJ} \cdot \mathrm{m}^{-2}$ (average incubation in the field was $489 \mathrm{~kJ} \mathrm{UV}-\mathrm{A} \cdot \mathrm{m}^{-2}$ ). Triplicate tubes wrapped in aluminum foil were used as controls. Immediately after incubation, the tubes were kept in the dark and $\mathrm{H}_{2} \mathrm{O}_{2}$ was measured 3, 7, 13, 26, and $51 \mathrm{~h}$ after irradiation was terminated. Half-lives were calculated from equations fitted $\left(r^{2}\right.$ values $\left.\geq 0.75\right)$ to $\geq 3 \mathrm{H}_{2} \mathrm{O}_{2}$ measurement points. Asymptotic decay phases were not in- cluded in these calculations. The temperature in the room was kept constant at $18{ }^{\circ} \mathrm{C}$ during the whole experiment.

\section{$\mathrm{H}_{2} \mathrm{O}_{2}$ measurements}

$\mathrm{H}_{2} \mathrm{O}_{2}$ concentrations were derived from the enzymecatalyzed reaction between APOXA and $\mathrm{H}_{2} \mathrm{O}_{2}$ to form a fluorescent product. Chemicals used during the study were obtained from Sigma Chemicals and used as received. APOXA and enzyme (horseradish peroxidase, Sigma Type VI, 50 units $\cdot \mathrm{mL}^{-1}$ ) stock and working solutions were prepared as described by Tranvik and Kokalj (1998). Briefly, $1.0 \mathrm{mg}$ of APOXA dissolved in $1 \mathrm{~mL}$ of dimethyl sulphoxide (DMSO) was used as the stock solution. Working solutions were prepared by mixing $25 \mu \mathrm{L}$ of the APOXA stock solution, $1 \mathrm{~mL}$ of Milli-Q water, and $2 \mathrm{~mL}$ of horseradish peroxidase. A volume of $90 \mu \mathrm{L}$ of the working solution was added to a $3-\mathrm{mL}$ sample in a $10-\mathrm{mL}$ acid- $(10 \% \mathrm{HCl})$ and Milli-Q-rinsed polypropylene vial. Depending on the time of sampling, fluorescence was measured after $1-10 \mathrm{~h}$ of cold storage on a Shimadzu RF-1501 spectrofluorometer with excitation and emission wavelengths of 570 and $585 \mathrm{~nm}$, respectively.

Owing to the possibility of dissolved organic matter affecting the calibration slopes of $\mathrm{H}_{2} \mathrm{O}_{2}$ measurements (Miller and Kester 1988), individual calibrations were performed for each lake studied. $\mathrm{H}_{2} \mathrm{O}_{2}$ volumes of $20-50 \mu \mathrm{L}$, serially diluted from a stock solution, were added to triplicate $3-\mathrm{mL}$ samples to achieve seven standard solutions ranging from 64 to $796 \mathrm{nmol} \cdot \mathrm{L}^{-1}$. Higher concentrations were analyzed by diluting the photoreacted sample with $0.2-\mu \mathrm{m}-\mathrm{mesh}$ filtered lake-specific water. The stock-solution concentration was determined and calibrated (molar absorptivity $38.1 \mathrm{~mol} \cdot \mathrm{cm}^{-1}$ ) (Miller and Kester 1988) from absorbance at $240 \mathrm{~nm}$, measured on a Beckman DU 650 spectrophotometer. Linear regression between standard $\mathrm{H}_{2} \mathrm{O}_{2}$ concentration and fluorescence for the different lakes presented slopes that ranged between 0.65 and 0.91 (all $r^{2}$ values $\geq 0.99$ ), depending on the lake water. A maximal error in calculated $\mathrm{H}_{2} \mathrm{O}_{2}$ concentrations of a factor of 1.6 could have resulted if we had used a single calibration curve for all studied lakes. This variation is considerably lower than the fourfold variation in calibration slopes noted for the $p$-hydroxyphenyl-acetic acid (POHPAA) method used to measure $\mathrm{H}_{2} \mathrm{O}_{2}$ in seawater (Miller and Kester 1988). APOXA exhibits fluorescence at wavelengths in the red region (approximately $580 \mathrm{~nm}$ ), where interfering fluorescence from dissolved organic matter is low. Analysis of freshwater samples is thus less problematic with APOXA because of lower background fluorescence (Lars Tranvik, Department of Limnology, Uppsala University, SE-752 36 Uppsala, Sweden, personal communication) compared with POHPAA, which exhibits fluorescence at approximately $350 \mathrm{~nm}$ (Miller and Kester 1988). However, although we detected a relatively small slope variation, calibrations are recommended for every type of lake studied. Blanks were obtained through a simplified version of the method used by Miller and Kester (1988). In contrast to their method, catalase was not added to degrade $\mathrm{H}_{2} \mathrm{O}_{2}$, since it did not affect the blank values of the samples.

Indications of temporal instability of sample fluorescence during field transport have previously been observed (Miller 
and Kester 1988). During the field measurements, the APOXA solution was added to the samples in the field, which were stored cool until further analysis in the laboratory. Storage time ranged from 4 to $10 \mathrm{~h}$. Therefore, we performed a stability test, covering the specific conditions present when the $\mathrm{H}_{2} \mathrm{O}_{2}$ measurements were done in the field. $\mathrm{H}_{2} \mathrm{O}_{2}$ was added to samples from each lake and to a Milli-Q sample used as a control, to a concentration of $322 \mathrm{nmol} \cdot \mathrm{L}^{-1}$. Samples were then stored as during field sampling. Fluorescence reading was followed by analyzing each sample five times over a 10-h period (i.e., the maximum amount of time between sampling and reading of fluorescence). We found a linear increase in fluorescence in all types of lakes as a function of storage time (all $r^{2}$ values $\geq 0.95$ ). The apparent increases in $\mathrm{H}_{2} \mathrm{O}_{2}$ concentration with storage time ranged between $4.3 \%$ and $37.3 \%$ for $10 \mathrm{~h}$ of storage in the cooling box $\left(4-10{ }^{\circ} \mathrm{C}\right)$, and were positively related to DOC concentration $\left(r^{2}=0.51, p<0.05\right)$. The Milli-Q control was stable for a period of $10 \mathrm{~h}(-0.02 \%$ change in fluorescence between initial reading and after $10 \mathrm{~h}$ storage). The magnitude of the increase in fluorescence in the clear-water lakes due to storage during our field measurements was comparable to the changes noted for the POHPAA reagent when used for $\mathrm{H}_{2} \mathrm{O}_{2}$ measurements in seawater (Miller and Kester 1988). The temporal increase in fluorescence due to storage that seems to prevail regardless of method or system studied should be considered when samples cannot be analyzed immediately. $\mathrm{H}_{2} \mathrm{O}_{2}$ concentrations during the diurnal and vertical profiles in all lakes presented here were corrected for the bias in fluorescence increase during storage before analysis.

\section{DOC concentrations, absorbance, metals, and statistics}

DOC concentrations were measured during the field study by the platinum-catalyzed high-temperature combustion method using a Shimadzu TOC-5000 total carbon analyzer equipped with an ASI-5000 autosampler (Granéli et al. 1996). A Beckman DU 650 spectrophotometer was used for absorption measurements and the absorptivity was calculated from the relationship 2.303.abs $\lambda \cdot l^{-1}$, where abs $\lambda$ is absorbance at wavelength $\lambda$ and $l$ is path length $(\mathrm{m})$. Total iron and manganese concentrations were determined through inductively coupled plasma-optical emission spectrometry, using a Perkin-Elmer model 3000 DV (Tyler and Olsson 2001). The reproducibility of the analysis was $\pm 5 \%$. Statistics were performed in GenStat (version 6.1 for Windows). Regressions were examined between $\mathrm{H}_{2} \mathrm{O}_{2}$ production and decay and between DOC and iron and manganese concentrations.

\section{Results and discussion}

$\mathrm{H}_{2} \mathrm{O}_{2}$ production and decay under laboratory conditions

Final $\mathrm{H}_{2} \mathrm{O}_{2}$ concentrations after $8 \mathrm{~h}$ of artificial irradiation under laboratory conditions were significantly correlated with neither absorption coefficients at $320 \mathrm{~nm}$ (data not shown) nor DOC concentrations in the lakes (Fig. 1a). However, a tendency toward a positive correlation between DOC and $\mathrm{H}_{2} \mathrm{O}_{2}$ concentrations could be discerned among lakes with DOC concentrations below $10 \mathrm{mg} \cdot \mathrm{L}^{-1}$. Scully et al. (1996) studied $\mathrm{H}_{2} \mathrm{O}_{2}$ formation in a range of waters with DOC concentrations up to $20.0 \mathrm{mg} \cdot \mathrm{L}^{-1}$. Those authors found a posi-
Fig. 1. Relationships between hydrogen peroxide $\left(\mathrm{H}_{2} \mathrm{O}_{2}\right)$ concentration after $8 \mathrm{~h}$ of exposure to ultraviolet (UV) radiation in the laboratory and dissolved organic carbon (DOC) concentrations (a) and half-lives of $\mathrm{H}_{2} \mathrm{O}_{2}(b)\left(y=592.4 x^{0.428}, r^{2}=0.62\right)$.
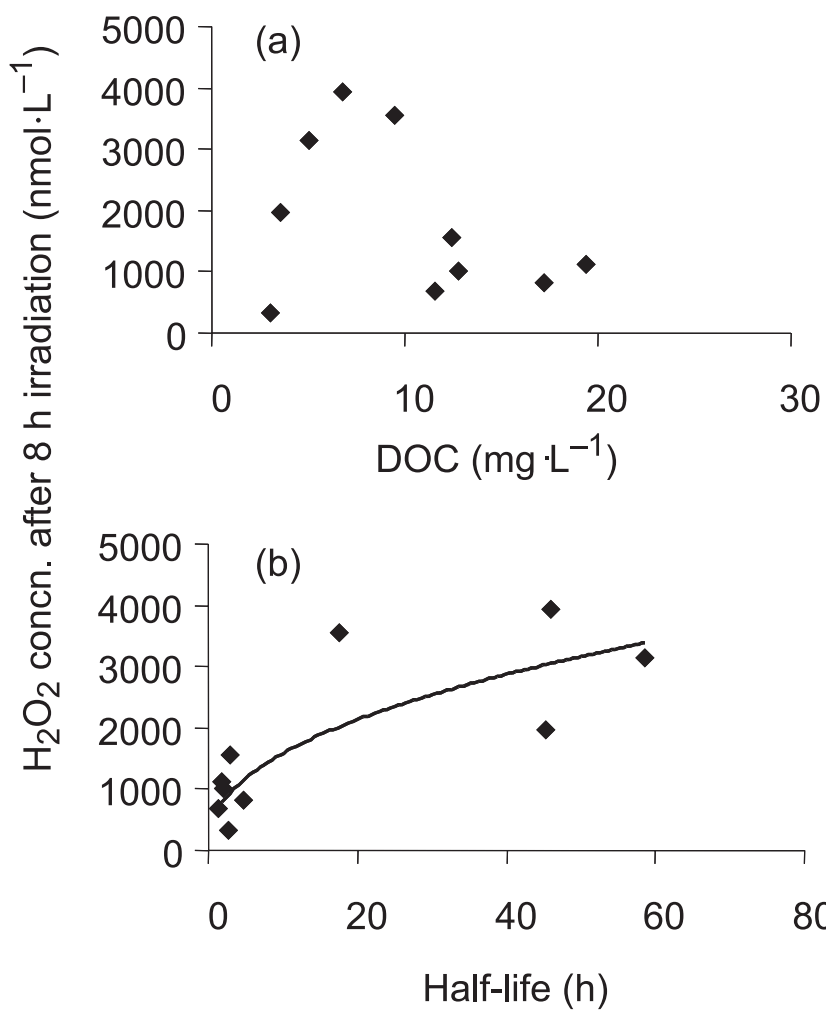

tive correlation between DOC concentration and $\mathrm{H}_{2} \mathrm{O}_{2}$ formation. However, Scully et al. (1996) only used waters with DOC concentrations in the range $1.4-7.6 \mathrm{mg} \cdot \mathrm{L}^{-1}$ in their regression between DOC concentration and $\mathrm{H}_{2} \mathrm{O}_{2}$. An aspect common to our study and the study of Scully et al. (1996) is the relatively high iron concentrations $\left(522-1240 \mu \mathrm{g} \cdot \mathrm{L}^{-1}\right.$; table 2 in Scully et al. 1996) in the high-DOC waters. Humic lakes usually contain high amounts of metals. Therefore, chemical decay can be very important in metal-rich waters, and the concentration of iron (Wilson et al. 2000a) and (or) manganese (Sunda and Huntsman 1994) may be more important than DOC concentration in explaining the variation in $\mathrm{H}_{2} \mathrm{O}_{2}$ concentration in fresh waters. Degradation of $\mathrm{H}_{2} \mathrm{O}_{2}$ through redox reactions between $\mathrm{H}_{2} \mathrm{O}_{2}$ and iron has been previously described (Voelker and Sulzberger 1996).

$\mathrm{H}_{2} \mathrm{O}_{2}$ half-lives ranged between 1.4 and $58.2 \mathrm{~h}$. When $\mathrm{H}_{2} \mathrm{O}_{2}$ concentrations at the end of the light incubations and $\mathrm{H}_{2} \mathrm{O}_{2}$ half-lives for the incubated waters are plotted together, a correlation between them can be seen (Fig. $1 b$ ). This suggests that the final $\mathrm{H}_{2} \mathrm{O}_{2}$ accumulation after $8 \mathrm{~h}$ of $\mathrm{UV}$ exposure in the studied lakes was largely determined by differing decay rates of $\mathrm{H}_{2} \mathrm{O}_{2}$. Therefore, our $\mathrm{H}_{2} \mathrm{O}_{2}$ concentration after $8 \mathrm{~h}$ of UV exposure may not represent real rates of $\mathrm{H}_{2} \mathrm{O}_{2}$ formation, since the final concentrations were largely offset by the low half-lives, especially those found in the metaland DOC-rich lakes. Therefore, it is likely that the lack of relationship between DOC concentration and $\mathrm{H}_{2} \mathrm{O}_{2}$ production found in our study was due to the long incubation time 
Fig. 2. Relationships between $\mathrm{H}_{2} \mathrm{O}_{2}$ decay in the laboratory and DOC $(a)$, iron $\left(y=98.9 x^{-0.576}, r^{2}=0.73\right)(b)$, and manganese $\left(y=28.2 x^{-0.716}, r^{2}=0.55\right)$ concentrations $(c)$.
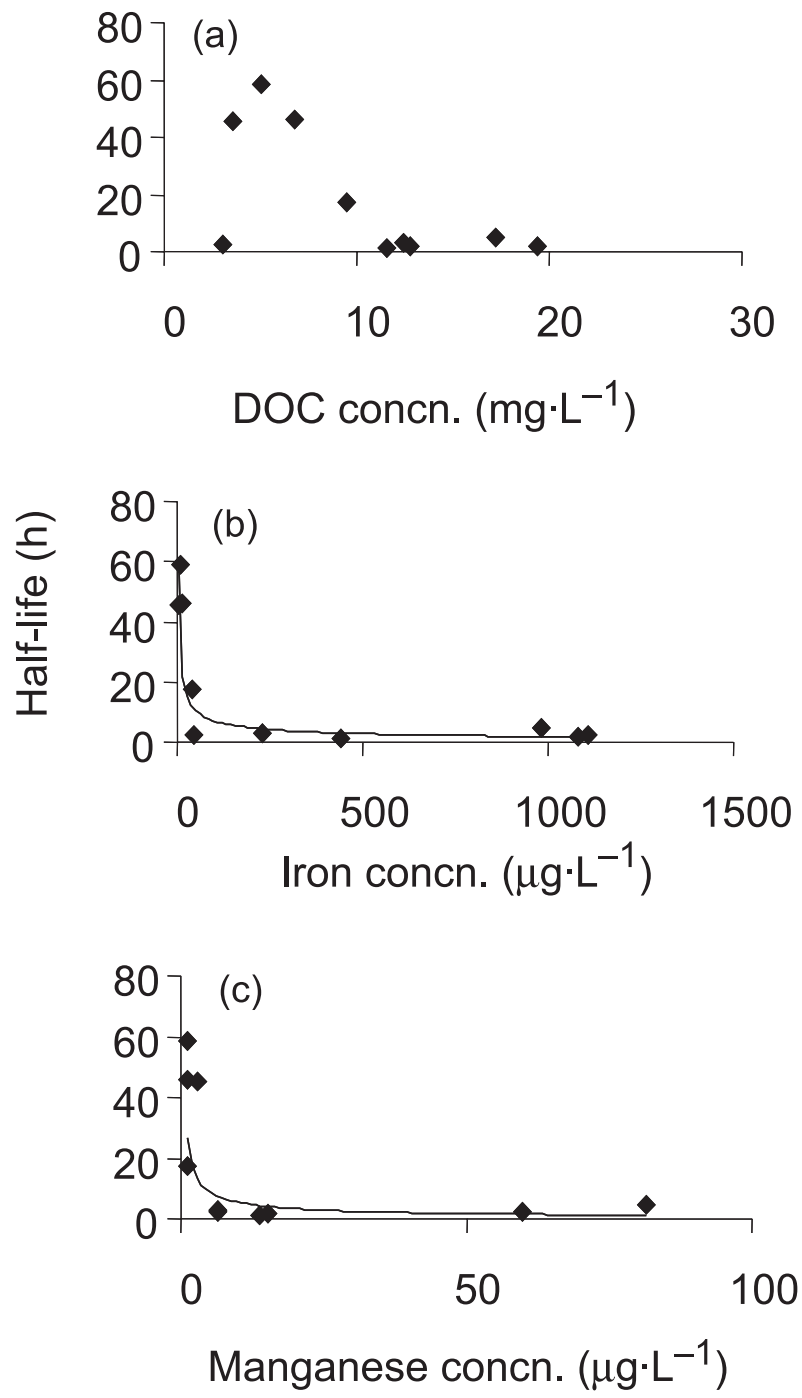

(i.e., measurements of $\mathrm{H}_{2} \mathrm{O}_{2}$ after $8 \mathrm{~h}$ of irradiation). However, even lakes with roughly similar DOC contents exhibited very different final $\mathrm{H}_{2} \mathrm{O}_{2}$ concentrations after $8 \mathrm{~h}$ of UV exposure (Fig. 1a), giving an indication that factors other than DOC may play an important role in explaining $\mathrm{H}_{2} \mathrm{O}_{2}$ production in fresh waters. We found a better negative power function relationship between $\mathrm{H}_{2} \mathrm{O}_{2}$ half-lives and metals $\left(r^{2}=0.73\right.$ and 0.55 with iron and manganese concentrations, respectively) than between $\mathrm{H}_{2} \mathrm{O}_{2}$ half-lives and DOC $\left(r^{2}=0.16\right)$ (Fig. 2). By studying lakes that differed in trophic status, Herrmann (1996) found that the half-life of $\mathrm{H}_{2} \mathrm{O}_{2}$ in DOC-rich waters was much shorter than in lowDOC waters, and concluded that chemical decay might be an important mechanism for explaining $\mathrm{H}_{2} \mathrm{O}_{2}$ decay in humic lakes. Two different types of $\mathrm{H}_{2} \mathrm{O}_{2}$-decay characters were detected among the lakes: (i) exponential (Lakes Klintsjön, Hindsen, Övingen, Homehultsjön, and Grunnen) and (ii) exponential followed by an asymptotic phase (Lakes Skärlen, Stråken, Stavsjön, Älgarydssjön, and Skärshultsjön)
Fig. 3. $\mathrm{H}_{2} \mathrm{O}_{2}$ concentrations in the dark $(0-51 \mathrm{~h})$ after $8 \mathrm{~h}$ of UV exposure in 3 out of 10 studied lakes. Decay of $\mathrm{H}_{2} \mathrm{O}_{2}$ in Lakes Grunnen $(\diamond)$ and Hindsen $(\square)$ fitted a first-order function, while $\mathrm{H}_{2} \mathrm{O}_{2}$ concentrations in Lake Älgarydssjön $(\triangle)$ exhibited asymptotic decay. Values are shown as the average minus the dark control.

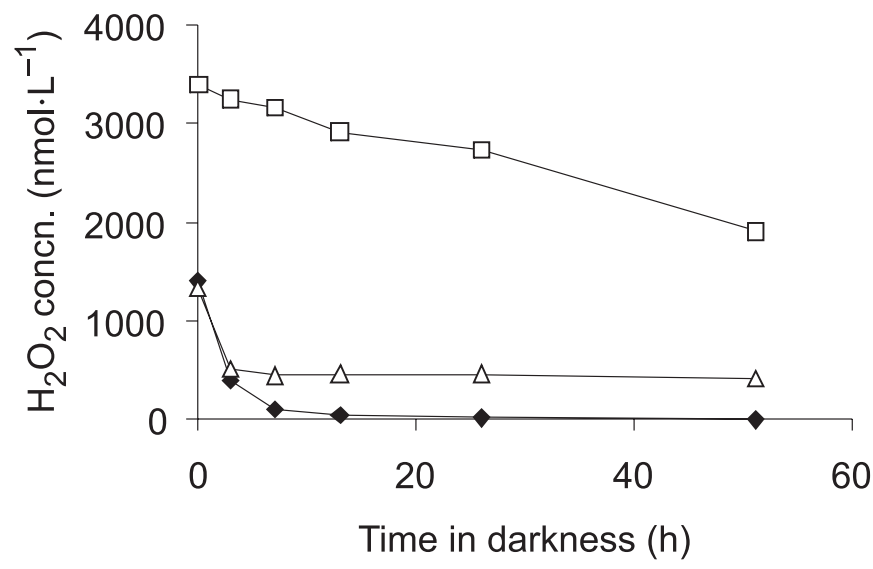

(Fig. 3). The asymptotic $\mathrm{H}_{2} \mathrm{O}_{2}$-decay behavior found in several of the metal-rich waters when radiation was interrupted might be explained by the complex relation between $\mathrm{H}_{2} \mathrm{O}_{2}$ and metals, since metals can form complexes, stabilize, and not react with $\mathrm{H}_{2} \mathrm{O}_{2}$ (Wilson et al. 2000a).

Abiotic production of $\mathrm{H}_{2} \mathrm{O}_{2}$ in the laboratory under artificial UV radiation correlated well with $\mathrm{H}_{2} \mathrm{O}_{2}$ production during the in situ incubations $\left(r^{2}=0.84, p<0.01\right)$, suggesting that under sterile conditions, the formation-decay equilibrium of $\mathrm{H}_{2} \mathrm{O}_{2}$ under artificial irradiation (i.e., only UV) is similar to that under natural irradiation (i.e., both PAR and UV). The in situ incubations showed, as was also indicated in the laboratory incubations, that there was no general correlation between the $\mathrm{H}_{2} \mathrm{O}_{2}$-producing capacities and the DOC concentrations of the studied lakes (data not shown).

\section{Diurnal and vertical variation in $\mathrm{H}_{2} \mathrm{O}_{2}$ concentration under in situ conditions}

The weather during the field study was predominantly warm and sunny, with integrated UV-A radiation values between 240 and $552 \mathrm{~kJ} \cdot \mathrm{m}^{-2}\left(\right.$ mean $\left.\pm \mathrm{SD}=462 \pm 113 \mathrm{~kJ} \cdot \mathrm{m}^{-2}\right)$. Water temperatures ranged from 10 to $25^{\circ} \mathrm{C}$ and the buildup of a diurnal stratification was noted on several occasions (data not shown).

The $\mathrm{H}_{2} \mathrm{O}_{2}$ concentration at the surface of the water column responded to the diurnal variation of light. The highest $\mathrm{H}_{2} \mathrm{O}_{2}$ concentrations were found in either the midday or the afternoon sampling. $\mathrm{H}_{2} \mathrm{O}_{2}$ concentrations ranged between 0 and $1041 \mathrm{nmol} \cdot \mathrm{L}^{-1}$ (Figs. 4 and 5). Maximum concentrations were always measured at the surface (i.e., at a few centimetres depth). $\mathrm{H}_{2} \mathrm{O}_{2}$ concentrations generally decreased with depth, but high concentrations could still be observed far below the $1 \%$ depth of radiation at $380 \mathrm{~nm}$, especially in the lakes with deeper epilimnia (e.g., Fig. 4a). This suggests that $\mathrm{H}_{2} \mathrm{O}_{2}$ produced at the surface mixes downward, and probably affects organisms and chemistry of lakes even in the layers where $\mathrm{H}_{2} \mathrm{O}_{2}$ is not produced (Scully and Vincent 1997).

The concentrations and distribution of $\mathrm{H}_{2} \mathrm{O}_{2}$ through the water column are explained by a combination of several fac- 
tors such as production capacity, decay rates, the depth of $1 \%$ surface irradiance in the UV range, cloud conditions, and the depth of the thermocline, among others (Cooper and Lean 1989; Kieber and Helz 1995; Herrmann 1996). $\mathrm{H}_{2} \mathrm{O}_{2}$ has previously been used as a chemical tracer for lake mixing (Scully and Vincent 1997; Scully et al. 1998). We chose some examples from our study to illustrate how several factors in combination might influence the vertical distribution of $\mathrm{H}_{2} \mathrm{O}_{2}$ in the water column in a complex way. Humic lakes such as Lake Grunnen (Fig. 4b) had high $\mathrm{H}_{2} \mathrm{O}_{2}$ concentrations at the surface, despite having very short $\mathrm{H}_{2} \mathrm{O}_{2}$ halflives, as verified in the laboratory experiments (Table 2). It is likely that the high $\mathrm{H}_{2} \mathrm{O}_{2}$ concentration at the surface of Lake Grunnen is maintained by a high level of $\mathrm{H}_{2} \mathrm{O}_{2}$ formation in combination with the fact that $\mathrm{H}_{2} \mathrm{O}_{2}$ is not lost downward because of the shallow epilimnion in Lake Grunnen. Lake Stråken, on the other hand, had a much deeper epilimnion, therefore most of the $\mathrm{H}_{2} \mathrm{O}_{2}$ produced at the surface was lost to deeper layers (Fig. 4c). In moderate-DOC lakes (e.g., Lake Hindsen), factors such as long half-lives of $\mathrm{H}_{2} \mathrm{O}_{2}$ and moderate epilimnion depth might contribute to the high $\mathrm{H}_{2} \mathrm{O}_{2}$ concentrations detected even in layers deeper than the $z 1 \%$ for UV radiation (Fig. $4 a$ ).

In this study we suggest that two main factors affect the $\mathrm{H}_{2} \mathrm{O}_{2}$ concentration at the surface of fresh waters: $(i)$ the depth of the epilimnion and (ii) the formation-decay equilibrium of $\mathrm{H}_{2} \mathrm{O}_{2}$. We used these two factors to explain the $\mathrm{H}_{2} \mathrm{O}_{2}$ concentration at the surface of the different lakes surveyed in this study. First, we corrected the $\mathrm{H}_{2} \mathrm{O}_{2}$ concentration at the surface of the different lakes at noon to an average amount of UV radiation during the period of the field sampling (i.e., the $\mathrm{H}_{2} \mathrm{O}_{2}$ concentration at an average amount of UV-A of $462 \mathrm{~kJ} \cdot \mathrm{m}^{-2}$ from 0900 to 1700 ). We made these corrections because the amount of irradiation received during the day varied among the lakes surveyed. Thereafter, we corrected the irradiation-normalized values for the dilution of $\mathrm{H}_{2} \mathrm{O}_{2}$ through mixing. This last correction was done simply by multiplying the irradiation-normalized surface $\mathrm{H}_{2} \mathrm{O}_{2}$ concentration by the depth of the epilimnion (Table 2). Based on this simplified model, we found a strong positive correlation between the half-lives of $\mathrm{H}_{2} \mathrm{O}_{2}$ and the surface $\mathrm{H}_{2} \mathrm{O}_{2}$ concentrations corrected by mixing depth $\left(r^{2}=0.81, p<0.01\right)$. We found no significant correlations between DOC concentration or absorptivity at $320 \mathrm{~nm}$ and surface $\mathrm{H}_{2} \mathrm{O}_{2}$ concentrations corrected by mixing depth. These results suggest that the half-lives of $\mathrm{H}_{2} \mathrm{O}_{2}$, which are strongly correlated with metals, and the depth of the epilimnion may be more important than DOC concentrations in explaining the $\mathrm{H}_{2} \mathrm{O}_{2}$ distribution in freshwater ecosystems. It should be noted that these results do not exclude the possibility that microorganisms play a role in $\mathrm{H}_{2} \mathrm{O}_{2}$ decay and distribution.

In two humic lakes, elevated $\mathrm{H}_{2} \mathrm{O}_{2}$ concentrations at $3 \mathrm{~m}$ depth were observed (i.e., Lakes Älgarydssjön and Skärshultsjön; Figs. $5 a, 5 c$ ). The high $\mathrm{H}_{2} \mathrm{O}_{2}$ concentration at $3 \mathrm{~m}$ depth, comparable to surface concentrations, could hardly be explained by vertically mixed $\mathrm{H}_{2} \mathrm{O}_{2}$ produced at the surface, since temperature-depth profiles showed a clear stratification in these lakes (i.e., temperature differences of up to $7{ }^{\circ} \mathrm{C}$ between the surface and $3 \mathrm{~m}$ depth). Trace metal mediated production of $\mathrm{H}_{2} \mathrm{O}_{2}$ in the dark (Moffett and Zika 1987)
Fig. 4. $\mathrm{H}_{2} \mathrm{O}_{2}$ depth profile throughout the day in Lakes Hindsen $(a)$, Grunnen $(b)$, and Stråken $(c)$. Values at $0930(\diamond), 1230(\square)$, and $1530(\bigcirc)$ are shown as the mean \pm standard deviation (SD) $(n=3)$. The bottom of the epilimnion is shown by the thermocline line.
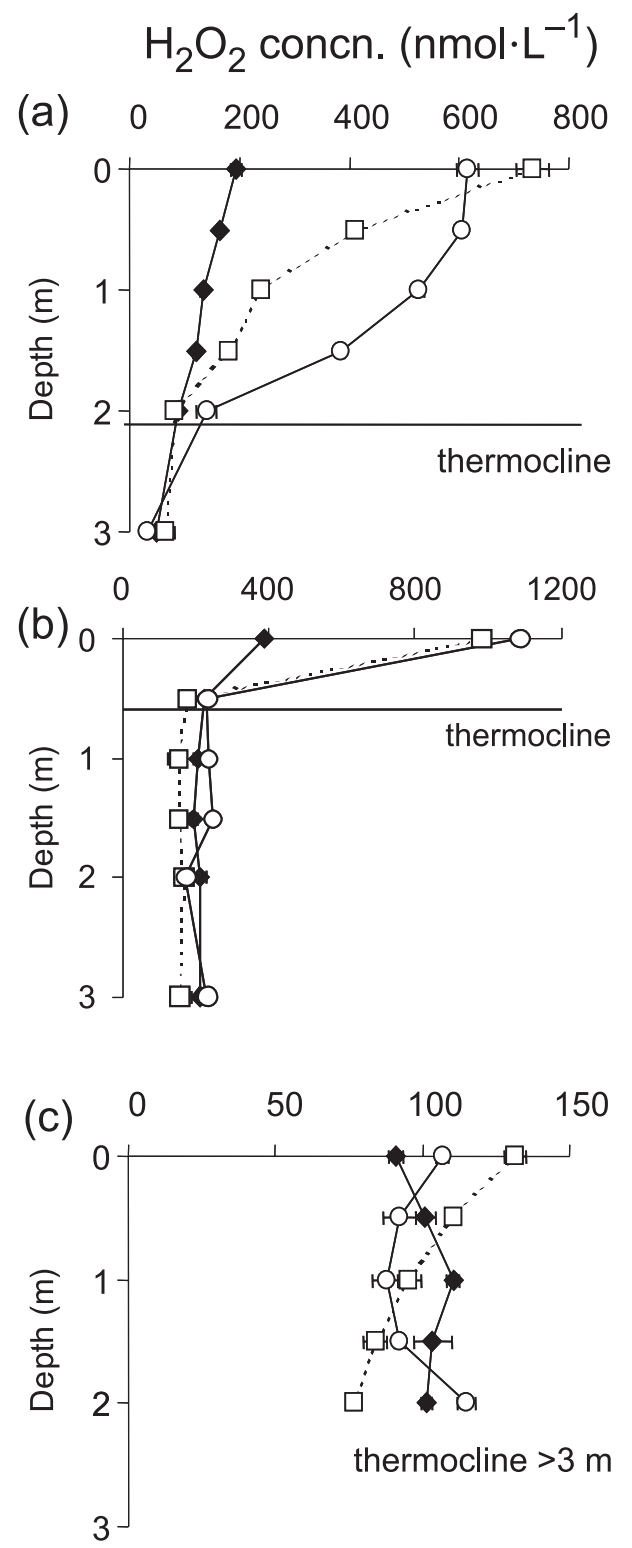

is a plausible explanation of this phenomenon. Asymptotic $\mathrm{H}_{2} \mathrm{O}_{2}$-decay characters, similar to those present in the laboratory incubations, could arise also under in situ conditions in stratified waters under low light conditions (both lakes exhibited the asymptotic $\mathrm{H}_{2} \mathrm{O}_{2}$-decay character in laboratory experiments). This suggests that if production in the dark was a significant factor, then higher levels of $\mathrm{H}_{2} \mathrm{O}_{2}$ could be maintained in the lower layers of a stratified water column because of asymptotic decay of $\mathrm{H}_{2} \mathrm{O}_{2}$. In Lakes Älgarydssjön and Skärshultsjön, a cold water mass was observed at $3 \mathrm{~m}$ depth during the day (i.e., the temperature was several degrees lower at 1230 and 1530 than at 0930 at the same depth; Figs. $5 b, 5 d$ ). It is worth noting that the decrease in temperature at $3 \mathrm{~m}$ depth during the day was only 
Fig. 5. $\mathrm{H}_{2} \mathrm{O}_{2}$ depth profiles ( $a$ and $c$ ) and temperature depth profiles ( $b$ and $d$ ) throughout the day in Lakes Älgaryssjön and Skärshultsjön, respectively. Values at $0930(\diamond), 1230(\square)$, and $1530(\bigcirc)$ are shown as the mean $\pm \mathrm{SD}(n=3)$.
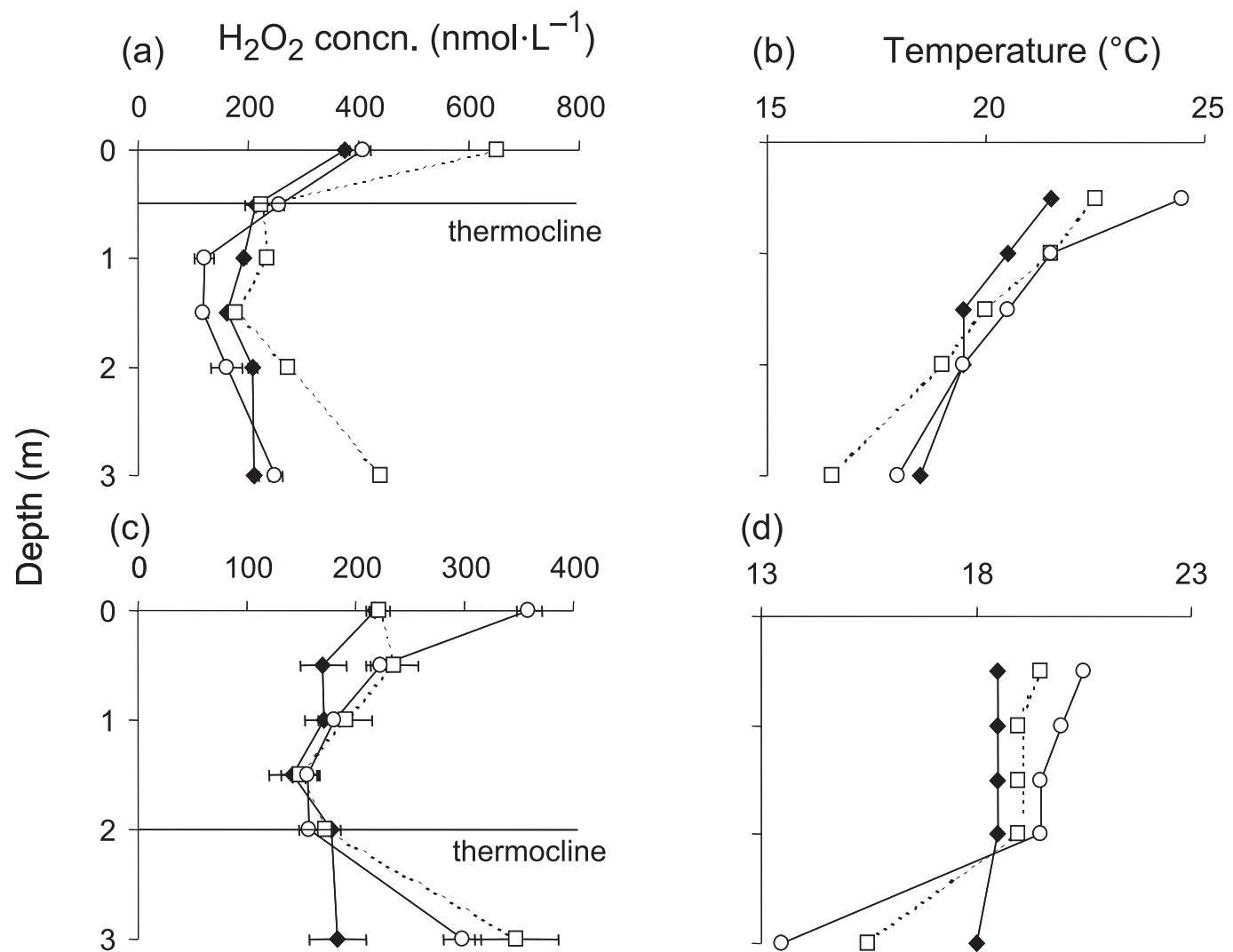

(d)

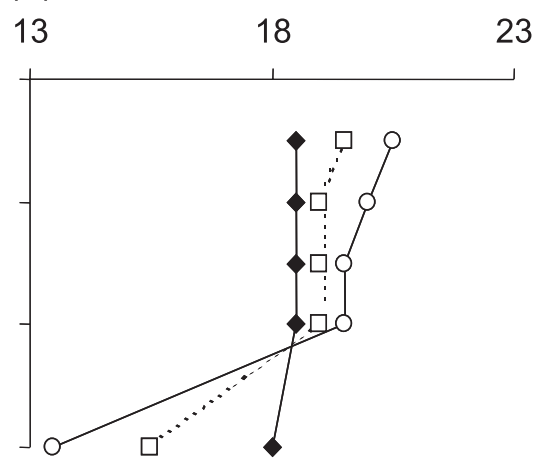

Table 2. Physical characteristics of the water column and surface $\mathrm{H}_{2} \mathrm{O}_{2}$ concentrations during field sampling, and half-lives of $\mathrm{H}_{2} \mathrm{O}_{2}$ in the studied lakes, obtained in the laboratory.

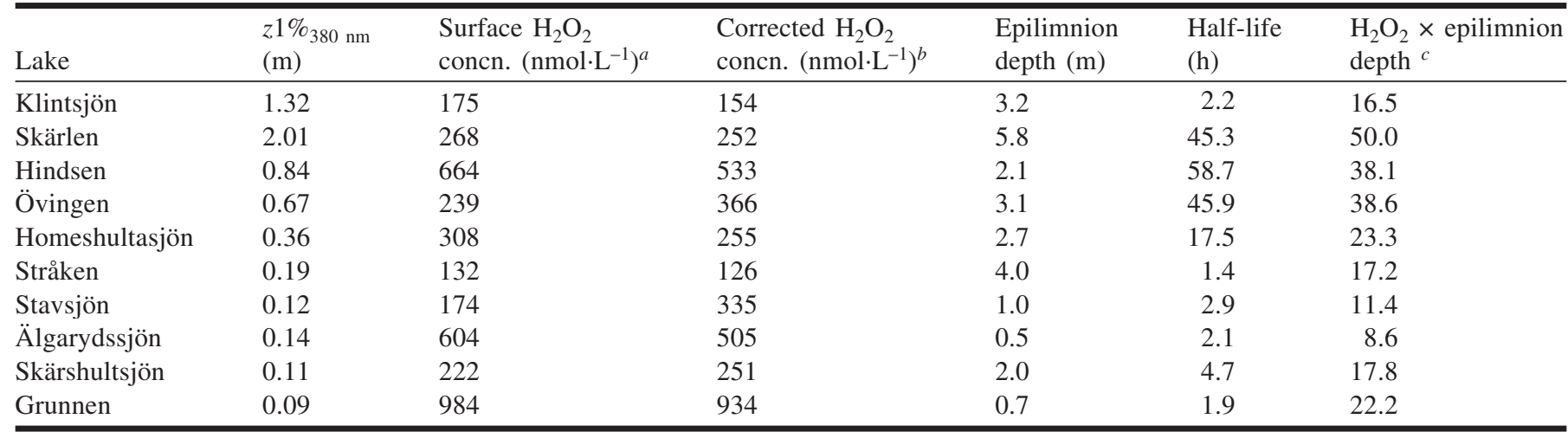

${ }^{a} \mathrm{H}_{2} \mathrm{O}_{2}$ concentration at the surface during the sampling at 1230 .

${ }^{b} \mathrm{H}_{2} \mathrm{O}_{2}$ concentration corrected for an average UV-A of $462 \mathrm{~kJ} \cdot \mathrm{m}^{-2}$ from 0900 to 1700 (i.e., surface concentration at $1230 / \mathrm{UV}-\mathrm{A}$ in that lake $\times 462$ ) (see Table 1).

${ }^{c}$ Corrected $\mathrm{H}_{2} \mathrm{O}_{2}$ concentration (see footnote $\left.b\right) \times$ epilimnion depth $\left(\mathrm{mg} \mathrm{H}_{2} \mathrm{O}_{2} \cdot \mathrm{m}^{-2}\right)$.

observed in these two lakes. The high $\mathrm{H}_{2} \mathrm{O}_{2}$ concentration, probably originating from the bottom of the lake, suggests that significant $\mathrm{H}_{2} \mathrm{O}_{2}$ production occurs under dark conditions. The same pattern has also been noted in other studies (Cooper et al. 1989a). Clearly, additional studies are necessary to understand the mechanisms behind $\mathrm{H}_{2} \mathrm{O}_{2}$ production in the dark, as well as its importance for $\mathrm{H}_{2} \mathrm{O}_{2}$ concentrations in deep waters of metal-rich lakes.

Based on the results of this study, we conclude that $\mathrm{H}_{2} \mathrm{O}_{2}$ distribution in boreal lakes can be highly variable, with no general correlation with DOC concentrations. Previous observations by Scully et al. (1995) have indicated a lack of correlation between DOC and $\mathrm{H}_{2} \mathrm{O}_{2}$ concentrations on an areal basis in Canadian lakes. We have shown in this study that measured $\mathrm{H}_{2} \mathrm{O}_{2}$ concentrations were largely determined by the differing decay rates of $\mathrm{H}_{2} \mathrm{O}_{2}$ and the mixing depth of the water column. In addition, we have shown that metals might substantially affect the decay of $\mathrm{H}_{2} \mathrm{O}_{2}$, and should be considered in further studies on the distribution of $\mathrm{H}_{2} \mathrm{O}_{2}$ in fresh waters, especially humic lakes. 


\section{Acknowledgements}

We thank Kelly Gutseit and Cesar Bolivar Daniel for their assistance during field sampling. Lars Tranvik gave valuable comments on the earlier version of the manuscript. This study was financed by the Swedish Research Council for Environment, Agriculture Sciences and Spatial Planning (FORMAS 21.4/2001-4022). Three anonymous reviewers also greatly improved the text.

\section{References}

Cooper, W.J., and Lean, D.R.S. 1989. Hydrogen peroxide concentration in a northern lake: photochemical formation and diel variability. Environ. Sci. Technol. 23: 1425-1428.

Cooper, W.J., and Zepp, R.G. 1990. Hydrogen peroxide decay in waters with suspended soils: evidence for biologically mediated processes. Can. J. Fish. Aquat. Sci. 47: 888-892.

Cooper, W.J., Zika, R.G., Petasne, R.G., and Plane, J.M.C. 1988. Photochemical formation of $\mathrm{H}_{2} \mathrm{O}_{2}$ in natural waters exposed to sunlight. Environ. Sci. Technol. 22: 1156-1160.

Cooper, W.J., Lean, D.R.S., and Carey, J.H. 1989a. Spatial and temporal patterns of hydrogen peroxide in lake waters. Can. J. Fish. Aquat. Sci. 46: 1227-1231.

Cooper, W.J., Zika, R.G., Petasne, R.G., and Fisher, A.M. $1989 b$. Sunlight induced photochemistry of humic substances in natural waters: major reactive species. Adv. Chem. Ser. No. 219. pp. 333-362.

Granéli, W., Lindell, M.J., and Tranvik, L.J. 1996. Photo-oxidative production of dissolved inorganic carbon in lakes of different humic content. Limnol. Oceanogr. 41: 698-706.

Herrmann, R. 1996. The daily changing pattern of hydrogen peroxide in New Zealand surface waters. Environ. Toxicol. Chem. 15: 652-662.

Kieber, R.J., and Helz, G.R. 1995. Temporal and seasonal variations of hydrogen peroxide levels in estuarine waters. Estuar. Coast. Shelf Sci. 40: 495-503.

King, D.W., Aldrich, R.A., and Charnecki, S.E. 1993. Photochemical redox cycling of iron in $\mathrm{NaCl}$ solutions. Mar. Chem. 44: $105-120$.

Kirk, J.T.O. 1994. Optics of UV-B radiation in natural waters. Ergebn. Limnol. 43: 1-16.

Mill, T., Hendry, D.G., and Richardson, H. 1980. Free-radical oxidants in natural waters. Science (Wash., D.C.), 207: 886-7.

Miller, W.L., and Kester, D.R. 1988. Hydrogen peroxide measurement in seawater by ( $p$-hydroxyphenyl) acetic acid dimerization. Anal. Chem. 60: 2711-2715.
Miller, W.L., and Kester, D.R. 1994. Peroxide variations in the Sargasso Sea. Mar. Chem. 48: 17-29.

Moffett, J.W., and Zafiriou, O.C. 1990. An investigation of hydrogen peroxide chemistry in surface waters of Vineyard Sound with $\mathrm{H}_{2}{ }^{18} \mathrm{O}_{2}$ and ${ }^{18} \mathrm{O}_{2}$. Limnol. Oceanogr. 35: 1221-1229.

Moffett, J.W., and Zafiriou, O.C. 1993. The photochemical decomposition of hydrogen-peroxide in surface waters of the Eastern Caribbean and Orinoco River. J. Geophys. Res. Oceans, 98: 2307-2313.

Moffett, J.W., and Zika, R.G. 1987. Reactions kinetics of hydrogen peroxide with copper and iron in seawater. Environ. Sci. Technol. 21: 804-810.

Scully, N.M., and Vincent, W.F. 1997. Hydrogen peroxide: a natural tracer of stratification and mixing processes in subarctic lakes. Arch. Hydrobiol. 139: 1-15.

Scully, N.M., Lean, D.R.S., McQueen, D.J., and Cooper, W.J. 1995. Photochemical formation of hydrogen peroxide in lakes: effects of dissolved organic carbon and ultraviolet radiation. Can. J. Fish. Aquat. Sci. 52: 2675-2681.

Scully, N.M., McQueen, D.J., Lean, D.R.S., and Cooper, W.J. 1996. Hydrogen peroxide formation: the interaction of ultraviolet radiation and dissolved organic carbon in lake waters along a $43-75^{\circ} \mathrm{N}$ gradient. Limnol. Oceanogr. 41: 540-548.

Scully, N.M., Vincent, W.F., Lean, D.R.S., and MacIntyre, S. 1998. Hydrogen peroxide as a natural tracer of mixing in surface waters. Aquat. Sci. 60: 169-186.

Sunda, W.G., and Huntsman, S.A. 1994. Photoreduction of manganese oxides in seawater. Mar. Chem. 46: 133-152.

Tranvik, L., and Kokalj, S. 1998. Decreased biodegradability of algal DOC due to interactive effects of UV radiation and humic matter. Aquat. Microb. Ecol. 14: 301-307.

Tyler, G., and Olsson, T. 2001. Plant uptake of major and minor mineral elements as influenced by soil acidity and liming. Plant Soil, 230: 307-321.

Voelker, B.M., and Sulzberger, B. 1996. Effects of fulvic acid on $\mathrm{Fe}(\mathrm{II})$ oxidation by hydrogen peroxide. Environ. Sci. Technol. 30: $1106-1114$

Wilson, C.L., Hinman, N.W., Cooper, W.J., and Brown, C.F. $2000 a$. Hydrogen peroxide cycling in surface geothermal waters of Yellowstone National Park. Environ. Sci. Technol. 34: 2655-2662.

Wilson, C.L., Hinman, N.W., and Sheridan, R.P. 2000b. Hydrogen peroxide formation and decay in iron-rich geothermal waters: the relative roles of abiotic and biotic mechanisms. Photochem. Photobiol. 71: 691-699.

Xenopoulos, M.A., and Bird, D.F. 1997. Effects of acute exposure to hydrogen peroxide on the production of phytoplankton and bacterioplankton in a mesohumic lake. Photochem. Photobiol. 66: $471-478$. 